\title{
Normal Pressure Hydrocephalus as Cause of Urinary Incontinence - A Shunt for Incontinence
}

\author{
Normaldruckhydrozephalus als Ursache der Harninkontinenz - \\ ein Shunt gegen Inkontinenz
}

Authors

Affiliation
R. Rendtorff, A. Novak, R. Tunn

Deutsches Beckenbodenzentrum, St. Hedwig-Krankenhaus, Berlin

\section{Key words \\ - urinary incontinence \\ - gynaecology \\ - post-menopause \\ Schlüsselwörter \\ - Harninkontinenz \\ - Gynäkologie \\ - Postmenopause}

\section{received $\quad 2.11 .2012$ \\ revised 21.11.2012 \\ accepted $\quad 22.11 .2012$}

Bibliography

DOI http://dx.doi.org/

10.1055/s-0032-1328066

Geburtsh Frauenheilk 2012; 72 :

1130-1131 @ Georg Thieme

Verlag KG Stuttgart · New York . ISSN 0016-5751

\section{Correspondence}

\section{Dr. Rosa Rendtorff, Dr. med.}

St. Hedwig-Krankenhaus

Deutsches Beckenbodenzentrum

Große Hamburger Straße 5-11

10115 Berlin

Rosa.Rendtorff@gmail.com

\section{Abstract \\ $\nabla$}

Normal pressure hydrocephalus is a frequently missed clinical entity with the typical symptom triad of gait disturbance, urinary incontinence and dementia (Hakim's triad) and occurs mostly from the 6th decade of life onwards. Early therapy can lead to a complete reversal of the symptoms. The present case report is intended to draw attention to the clinical entity normal pressure hydrocephalus (NPH) since the afflicted patients often primarily consult a gynaecologist on account of the urinary bladder disorders.

\section{Case History and Findings}

An 83-year-old woman presented with subjective urge symptoms, persistent urinary incontinence and additionally for the past 3 months faecal incontinence when under stress. For the past 2 years the urinary incontinence took the form of urge incontinence. Oestrogenisation and therapy with various anticholinergic agents had not shown any effects as yet. A urodynamic examination revealed a motoric urge, a urethral pressure profile without continence zone and a limited bladder capacity of $110 \mathrm{~mL}$.

The diagnosis of mixed urinary incontinence was made and a diagnostic cystoscopy was performed with hypodistension of the urinary bladder as well as intravesical injection of $100 \mathrm{IU}$ botulinum toxin. In addition, therapy with oral Yentreve $1 \times 20 \mathrm{mg}$ per day was initiated, increasing to $2 \times 40 \mathrm{mg}$ in the further course.

\section{Course und Therapy}

Ten months later with continuing urinary and faecal incontinence and considerable psychological stress, the patient was referred to a neurolo-

\section{Zusammenfassung}

$\nabla$

Der Normaldruckhydrozephalus ist ein häufig übersehenes Krankheitsbild mit der typischen Trias aus Gangstörung, Harninkontinenz und Demenz (HAKIM-Trias) und tritt gehäuft ab dem 6. Lebensjahrzehnt auf. Eine frühzeitige Therapie kann zur vollständigen Reversibilität der Symptome führen. Das folgende Fallbeispiel soll das Krankheitsbild Normaldruckhydrozephalus (normal pressure hydrocephalus, NPH) in Erinnerung rufen, da sich Betroffene auf Grund von Blasenfunktionsstörungen oft primär beim Frauenarzt vorstellen.

gist. For about one year there had been a progressive gait disturbance with a small-step and widebased gait, also in the previous months a memory disorder with deterioration of the short-term memory became apparent.

Computed tomography revealed a markedly extended ventricle system in the sense of normal pressure hydrocephalus. Performance of a spinal tap test was unsuccessful due to the known Bekhterev's disease. On the basis of the presence of the typical Hakim triad and radiological signs for $\mathrm{NPH}$, the decision was made to implant a ventriculo-peritoneal shunt system with a MedosHakim pressure valve. A marked improvement of gait was already apparent just a few days after shunt implantation. Three months after shunt implantation the patient was continent and, with the exception of slight gait unsteadiness, able to walk without any aids.

\section{Epidemiology}

Normal pressure hydrocephalus occurs more frequently in the 6th and 7th decades of life, the gender distribution is almost exactly balanced. The exact prevalence of NPH is not clear, estimates 
vary between from $0.003 \%$ of under 65 -year-olds and $0.2-2.9 \%$ of over 65-year-olds [1-3]. A very large grey zone is assumed for the disease.

\section{Definition}

An NPH is present when the amount of CSF is increased while CSF pressure is usually within the normal range. However, the term normal pressure hydrocephalus is misleading as there are temporary pressure increases with nocturnal peaks. The aetiology of NPH is not completely clarified; a resorption disorder and misbalance between CSF production and resorption are assumed. The increase of the amount of CSF leads to the characteristic ventricle distension and periventricular oedema formation which, in turn, cause a functional reduction in perfusion [4].

\section{Causes}

\section{$\nabla$}

A distinction is made between primary idiopathic and secondary $\mathrm{NPH}$, which are about equally prevalent. Causes of secondary NPH are, for example, subarachnoid haemorrhage, trauma, infection or tumour disease [5].

\section{Clinical Picture}

$\nabla$

The typical Hakim's triad is predominant: gait disturbance, dementia, and urinary incontinence. The gait disturbance features a broad-based, small-step, magnetic gait with the feet turning outwards, resembling that of patients with Parkinson's disease [6]. The memory disorders mainly involve a deterioration of the short-term memory; frequently the patient's executive functions are impaired [1]. Urinary incontinence occurs in about $45-90 \%$ of $\mathrm{NPH}$ patients. There is mostly a neurogenic disturbance of micturation, especially as the way to the toilet is more difficult due to the presence of the gait disturbance [4]. In the further course a functional disorder of the frontal lobe prevents recognition of the urinary urge. The bladder disorders in NPH are the result of a hyperactive detrusor muscle due to reduced or absent central inhibition. At first the patient suffers from an increased micturition frequency. In the further course, urge incontinence usually follows and can progress to an absolute urinary incontinence. Faecal incontinence usually only occurs in the advanced stages [1]. The presence of 2 of the 3 criteria is necessary to make the diagnosis, the gait disturbance is considered as obligatory. Diseases such as Parkinson's disease, Alzheimer's disease, vascular dementia or Lewy body disease are some of the differential diagnoses.

\section{Diagnostics}

A cranial CT or MRI should be performed in order to demonstrate the typical ventricular enlargements. In the so-called spinal-tap test $30-50 \mathrm{~mL}$ of CSF are removed which, in the case of NPH, leads to a temporary improvement of the symptoms. A long-term CSF puncture with pressure measurement or intracranial pressure measurements are also possible [7].

\section{Therapy}

\section{$\nabla$}

As therapy for NPH a shunt is inserted for long-term CSF drainage. In most cases, ventriculo-peritoneal shunts are used; ventriculo-atrial shunts represent an alternative. Over- or underdrainage can be avoided by means of programmable pressure valves. For multimorbid, inoperable patients intermittent therapeutic CSF punctures can be performed as an alternative.

\section{Prognosis \\ $\nabla$}

The success rates of shunt operations are high; a subjective improvement of the complaints is seen postoperatively in about $96 \%$ of the patients. In $83 \%$ of the patients an improvement of the gait disturbance can be seen after 6 months. An improvement in urinary incontinence occurs in 50-90\%. It must be emphasised here that early treatment leads to high success rates $[1,8,9]$.

\section{Conclusion for Practitioners \\ $\nabla$}

In the urogynaecological examination of female patients with urinary incontinence, especially elderly multimorbid patients, the clinical entity normal pressure hydrocephalus is often not taken into account.

When the patient exhibits a gait disturbance on the way to the examination chair, the possibility of NPH should be considered and the patient questioned about a temporal relationship between the symptoms. An early diagnosis of the problem can spare the patient from a long period of suffering and possibly irreversible pressure damage to the brain.

\section{Conflict of Interest}

$\nabla$

None.

\section{References}

1 Kiefer M, Unterberg A. Differenzialdiagnose und Therapie des Normaldruckhydrozephalus. Dtsch Arztebl 2012; 109; 1-2: 15-26

2 Krauss JK, Halve B. Normal pressure hydrocephalus: survey on contemporary diagnostic algorithms and therapeutic decision-making in clinical practice. Acta Neurochir (Wien) 2004; 146: 379-388

3 Brean A, Fredø H, Sollid $S$ et al. Five-year incidence of surgery for idiopathic normal pressure hydrocephalus in Norway. Acta Neurol Scand 2009; 120: 314-316

4 Paulus W et al. Leitlinien der DGN, Deutsche Gesellschaft für Neurologie, Normaldruckhydrozephalus, 2008, www.dgn.org/images/stories/ dgn/leitlinien/LL2008/l108kap_017.pdf

5 Gautschi $O$, Cadosch D, Stienen $M$ et al. Idiopathischer Normaldruckhydrozephalus. Idiopathic Normal Pressure Hydrocephalus. Praxis (Bern 1994) 2009; 98: 893-902

6 Stolze H, Kuhtz-BuschbeckJP, Drücke H et al. Comparative analysis of the gait disorder of normal pressure hydrocephalus and Parkinson's disease. J Neurol Neurosurg Psychiatry 2001; 70: 289-297

7 Marmarou A, Young H, Aygok G et al. Diagnosis and management of idiopathic normal-pressure hydrocephalus: a prospective study in 151 patients. J Neurosurg 2005; 102: 987-997

8 Gallia G, Rigamonti D, Williams M. The diagnosis and treatment of idiopathic normal pressure hydrocephalus. Nat Clin Pract Neurol 2006; 2: 375-381

9 McGirt M, Woodworth G, Coon A et al. Diagnosis, treatment, and analysis of long-term outcomes in idiopathic normal-pressure hydrocephalus. Neurosurgery 2008; 62 (Suppl. 2): 670-677

Deutschsprachige Zusatzinformationen online abrufbar unter:

www.thieme-connect.de/ejournals/toc/gebfra. 